\title{
SYNOPTIC ANALYSIS OF THE FLASH FLOOD IN GÖKÇEADA/TURKEY BY USING MSG SATELLITE DATA AND WEATHER CHARTS
}

DOI: http://dx.doi.org/10.18509/GBP.2015.23

UDC: 551.589:551.577.61-047.44(560)

\author{
Serhan YEŞILKÖYY,2 \\ Dr. Ahmet ÖZTOPAL ${ }^{1}$ \\ ${ }^{1}$ Istanbul Technical University, Faculty of Astronautics and Aeronautics, Department of \\ Meteorological Engineering. 34469, Maslak, Istanbul, Turkey. \\ ${ }^{2}$ Atatürk Soil, Water and Agricultural Meteorology Research Station Directorate. 39010, \\ Kırklareli, Turkey.
}

\begin{abstract}
Developments in science and technology pave the way for remote sensing technologies in meteorology in recent years. Especially, increasing resolution and number of channel is easier to understand and to assess meteorological patterns and disasters. According to IPCC reports, Mediterranean Basin will be one of the most affected area by climate change. So that, frequency and power of hurricanes associated with climate change in Mediterranean Area have remained. It is observed that flash floods have occurred more frequent like İstanbul and Samsun flash flood in Turkey. A supercell over Gökçeada caused rainfall about $144 \mathrm{~mm}$ in 4 hours and damaged materially and spiritually on living people. This paper presents the imaging water vapor channels, RGB combinations, and synoptic analysis of Gökçeada flash flood in May 2014.
\end{abstract}

Keywords: MSG data, satellite meteorology, flash flood, Gökçeada/Turkey.

\section{INTRODUCTION}

Floods are one of the most hazardous events in nature. It becomes important to determination and forecasting of floods. Requirement of forecasting excessive precipitation comes up for this reason. An active radar as a remote sensor has started to using from Second World War for precipitation (Battan and Braham, 1956). Remote sensing image registration system has been widely applied for agriculture, forestry, geology, ocean, meteorology, hydrology and military field. Despite the first meteorological image from satellite in 1977, high resolution images could be attained after 2002 from MeteoSat Second Generation (Schmetz et al., 2002). Images associated with high resolution sensors from satellites are more noticeable. During night time, satellite cannot visible channel lack of sunshine.

"Red, Green, Blue" or RGB processing offers a simple and powerful solution to characterize what you are focused on. It consolidates the information from different spectral channels into single products that provide more information than any one image can provide (MetEd, 2013).

According to IPCC fifth assessment report, climate change will effect Mediterranean Area and Black Sea (2013). It could certainly observed that intensity of rainfall increased in contrast with frequency decreased (Dankers and Feyen, 2009). Besides, insensible urbanization and constructions in stream bed cause not only pecuniary loss and intangible damages but also loss of lives. Floods are the second most destructive type of natural disaster in Turkey, after earthquakes. Approximately $30 \%$ of all the natural disasters in the country consist of flood events. According to EM-DAT database, 34 flood events 
occurred in Turkey between 1950 and 2007 and 1016 people died, and about 1.5 million people were affected (EM-DAT, 2010).

In this paper, it is aimed understanding of flash flood's dynamics on $2^{\text {nd }}$ of May in 2014 in Gökçeada. The paper is organized as follows. Section 2 describes the study region and evaluated rainfall from 00:00 AM to 04:00 AM as a local time on $2^{\text {nd }}$ of May in 2014. Section 3 includes synoptic and MSG data analysis and RGB applications for different MSG channels. Section 4 summarizes results and discussions.

\section{STUDY AREA and DATA}

Study area is Gökçeada, the biggest island with a $287 \mathrm{~km}^{2}$ surface area, which is located in western part of Turkey. It spans from $40^{\circ} 05^{\prime} 42.87^{\prime \prime} \mathrm{N}$ to $40^{\circ} 14^{\prime} 24.12^{\prime \prime} \mathrm{N}$ in latitude, and from $25^{\circ} 39^{\prime} 53.23^{\prime \prime} \mathrm{E}$ to $26^{\circ} 00^{\prime} 57.71^{\prime \prime} \mathrm{E}$ in longitude (Figure 1).

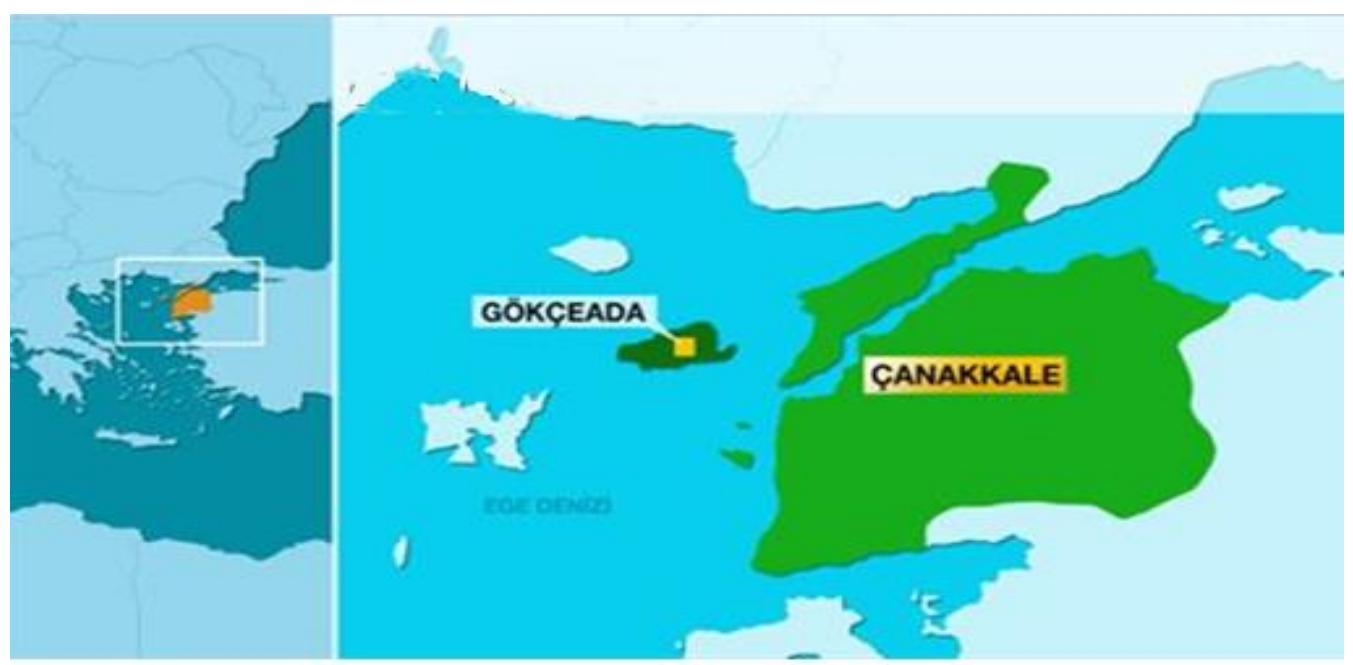

Figure 1. Location of Study Area - Gökçeada

According to Turkish Meteorological Service's data, rainfall occurred between 00:10 AM and 04:00 AM as a local time. Total amount of precipitation was $144.4 \mathrm{~mm}$ in this time period and break a new record. Mr. Ünal Çetin, Gökçeada Mayor, indicated that the conditions of district was considerable desperate. He also wanted that the area was urgently announced as a disaster area and that a commission was createad to determine and repair damage. There were many things to be damaged such as vehicles, houses, offices, of course people and animals (Fig. 2 and Fig. 3).

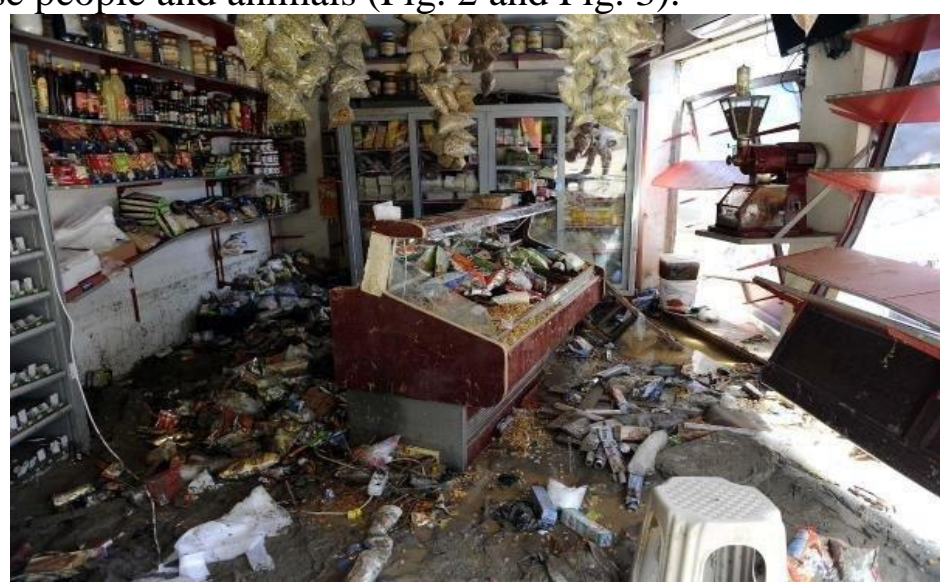

Fig. 2. An Example of Damaged Shop 


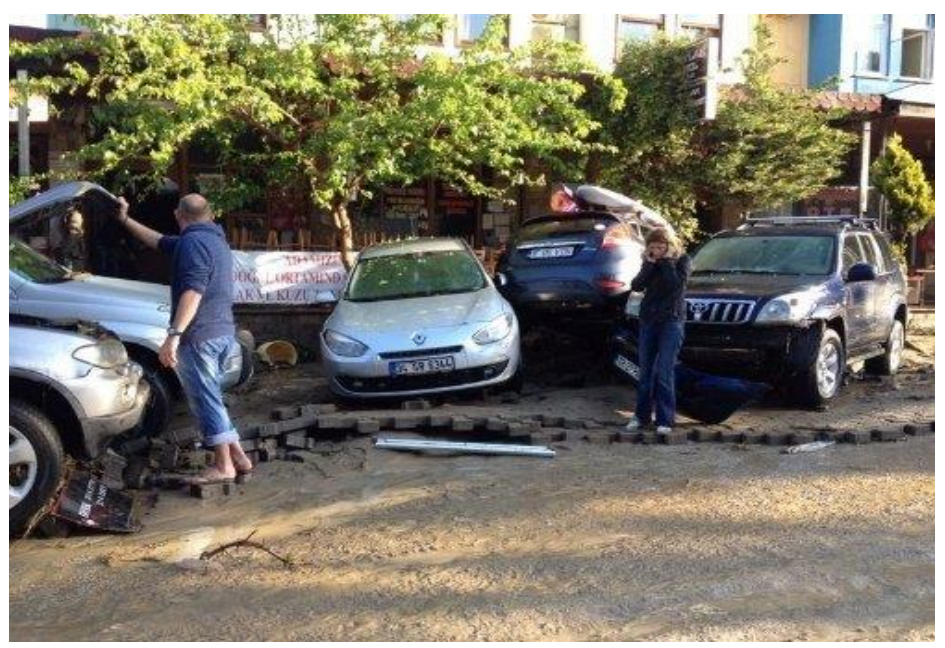

Fig. 3. Some Damaged Cars

\section{RESULTS and DISCUSSION}

In Figure 4 there is a trough, low pressure area or cyclone in Aegean Sea at 9 PM before flood. On the other hand, low pressure area was occurred near Gökçeada because of this trough. Existence of this occluded system shows us to be developed this time period. Scale of supercell over Gökçeada is small because frontal area is not very large.

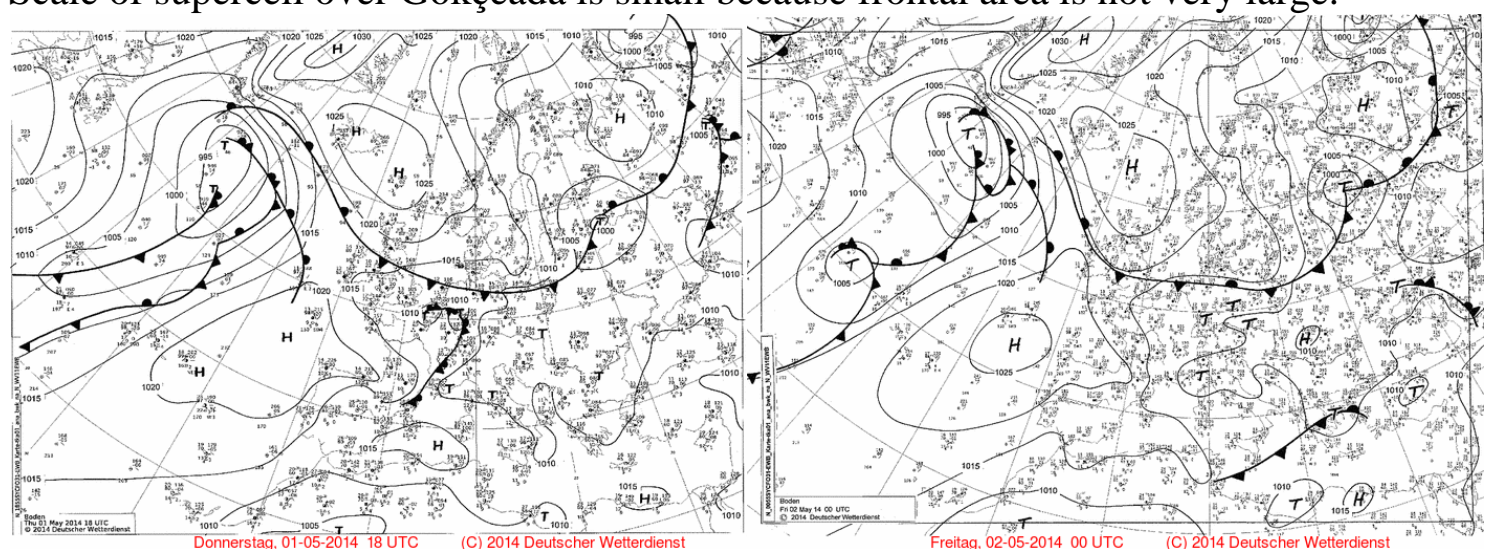

Figure 4. Sea Level Pressure and Front Maps

In Figure 5, there is $6^{\circ} \mathrm{C}$ isotherm is on Gökçeada. Circulation of wind brings warm air to this area. This circulation cause developing this supercell system.
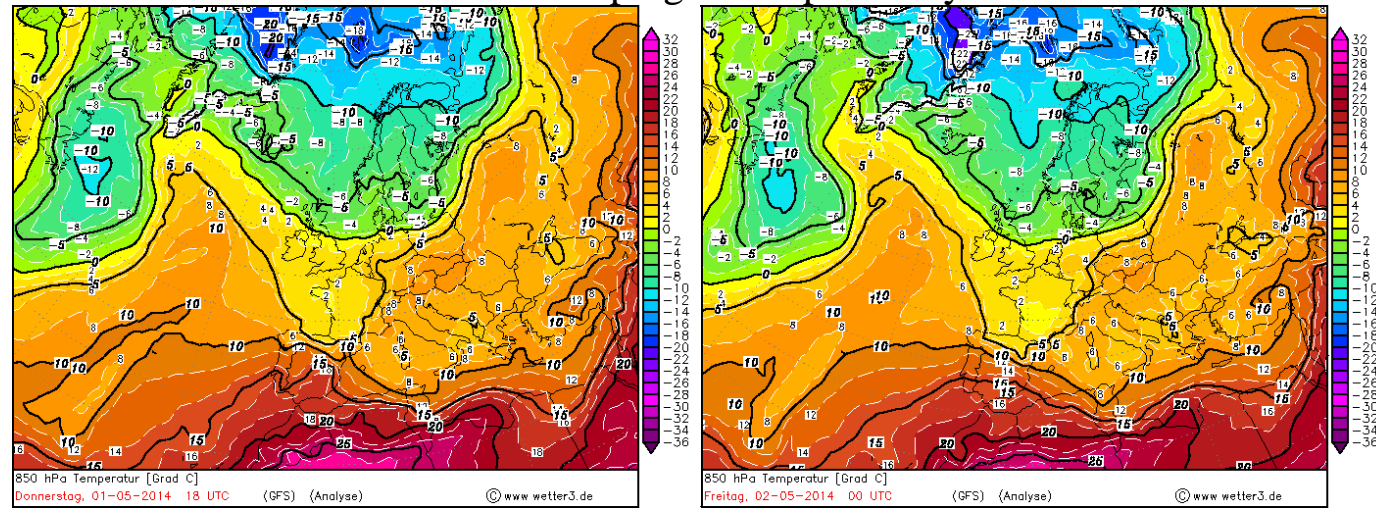

Figure 5. $850 \mathrm{hPa}$ Geopotantial Height and Temperature Maps 
In Figure 6, there is a depression in south Marmara which creates a positive vorticity area in northern Aegean Sea including Gökçeada. This situation appears upward vertical wind. That is why supercell develops in a short time period.
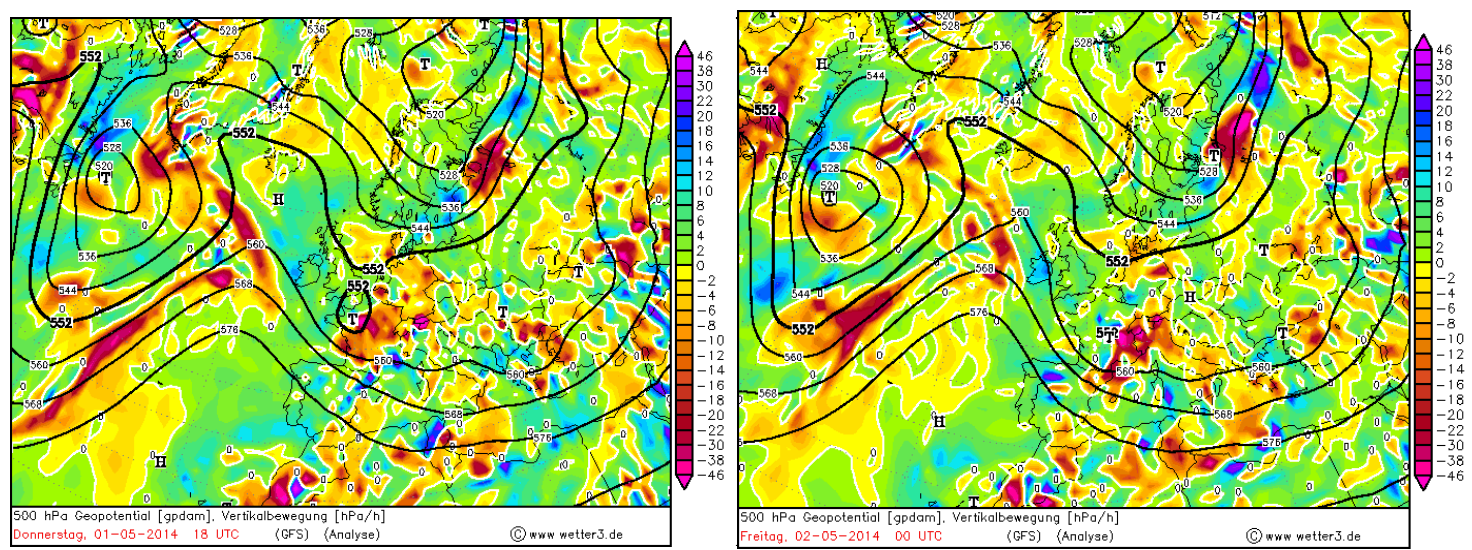

Figure 6. $500 \mathrm{hPa}$ Geopotantial Height and Vorticity Maps

In Figure 7, lifted index (LI) and convective available potential energy (CAPE) values are respectively -2 and 700 over Aegean Sea. These high values supplies energy for developing supercell. Intensity of supercell may be increased by these conditions.
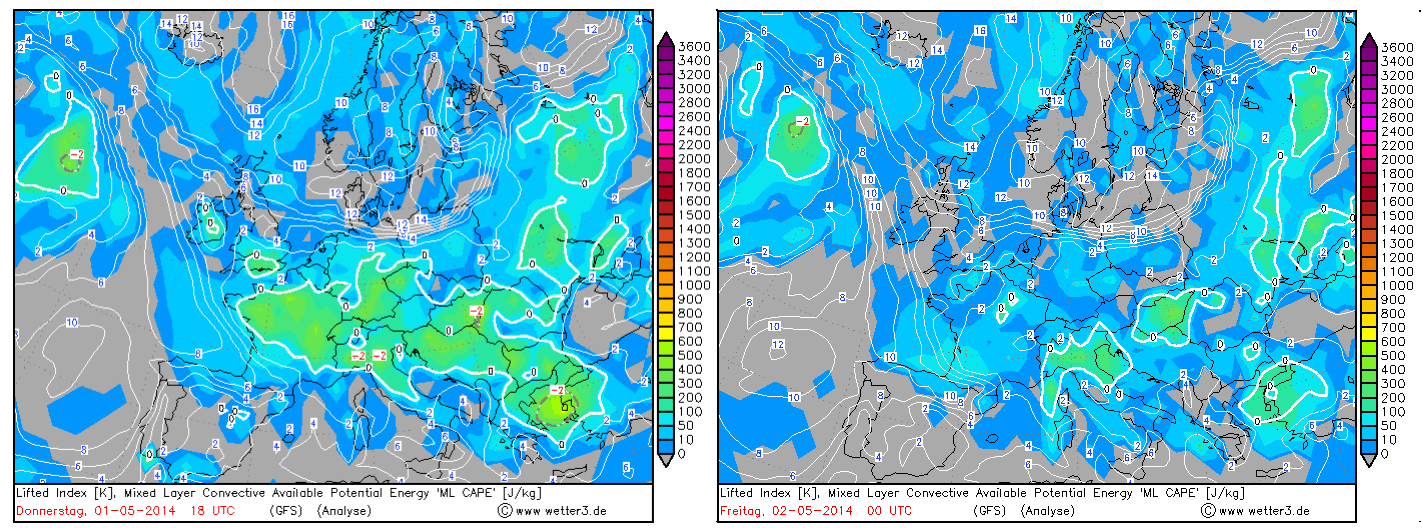

Figure 7. Lifted Index [K], Mixed Level Convective Available Potential Energy ML CAPE [J/kg]

In Figure 8, there is a depression at $300 \mathrm{hPa}$ level, which supplies energy for developing this supercell at 9 PM. Jet stream values 100 knots at 3 AM that cause losing energy and disperse in the direction of jet stream.
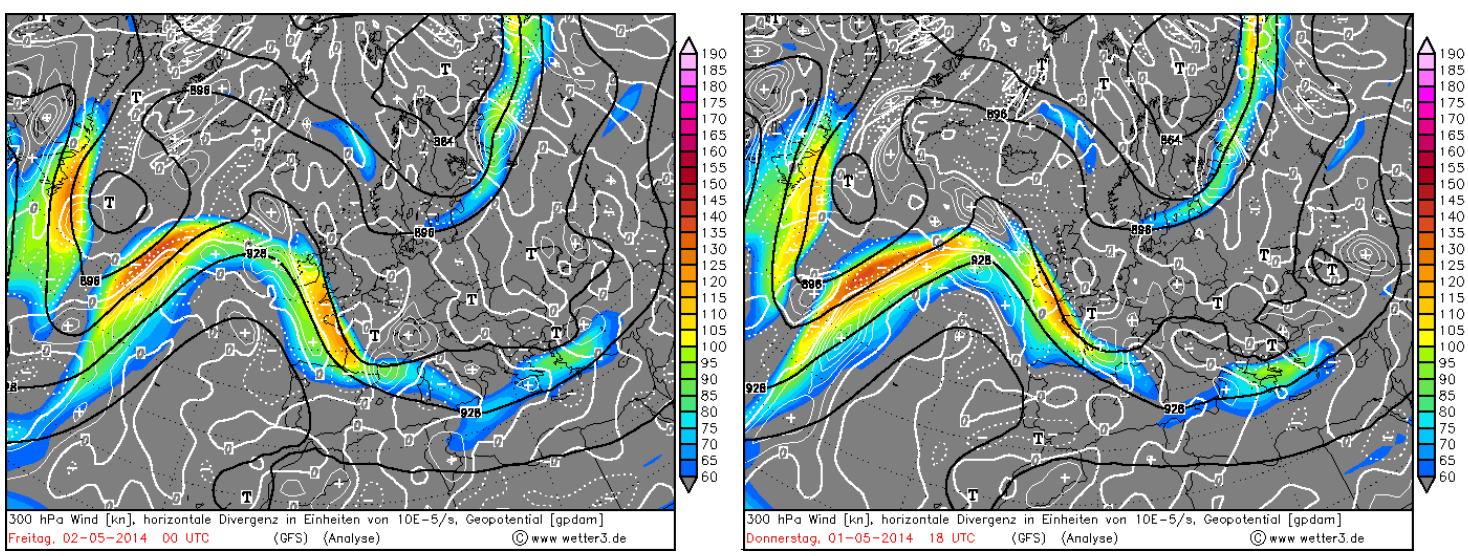

Figure 8. 300 hPa Jetstream Wind 
Figure 9 illustrates MSG satellite channels normalized weighting function. In this paper, WV $7.3 \mu \mathrm{m}$ channel that get information from $500 \mathrm{hPa}$ level and IR $10.8 \mu \mathrm{m}$ that is sensitive to clouds' top temperature.

\section{Standard Mid-Latitude Summer Nadir}

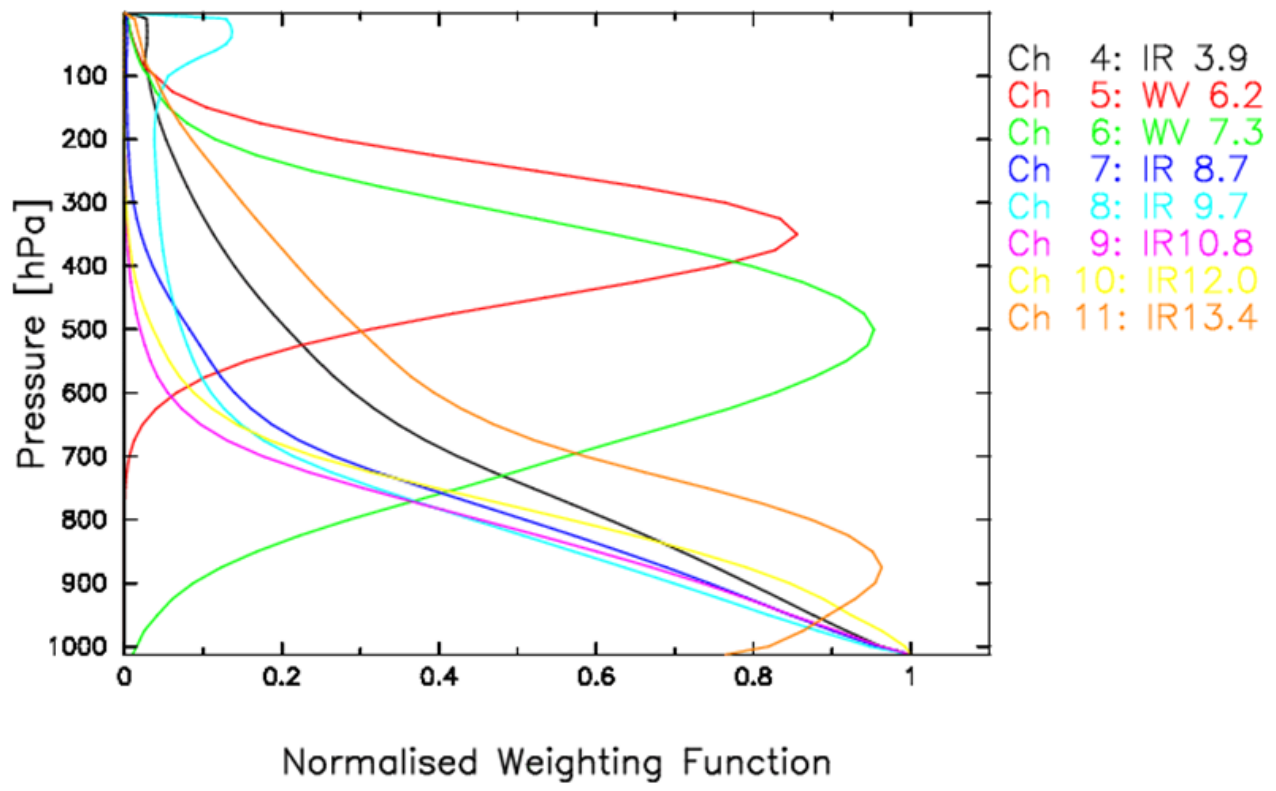

Figure 9. MSG Channels with Normalized Weighting Functions

Figure 10 illustrates beginning, development, and dispersion of supercell with 30 minutes timestamp. Especially, maximum energy can be seen at 02:30 and 03:00 AM. Its dispersion gets faster after $04 \mathrm{AM}$ by jet streams.

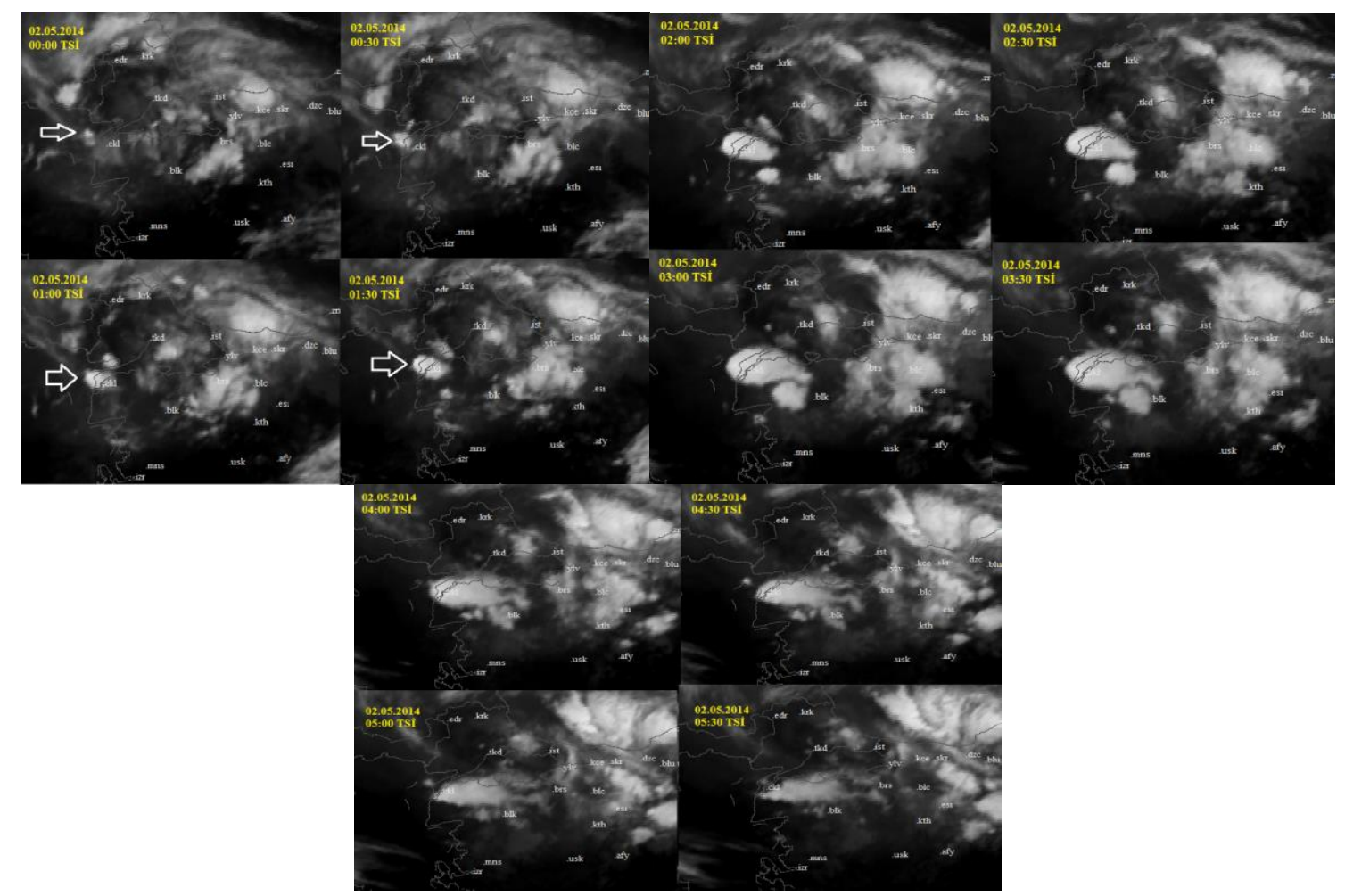

Fig. 10. WV Channel 7.3 TMetVis Visualizations 
It is used IR channel $10.8 \mu \mathrm{m}$ which is sensitive to temperature and supercell values $55^{\circ} \mathrm{C}$ from 01:30 AM to 03:30 AM. Temperature legend is between $-20^{\circ} \mathrm{C}$ and $-60^{\circ} \mathrm{C}$ to focus on better visualization of supercell (Figure 11).

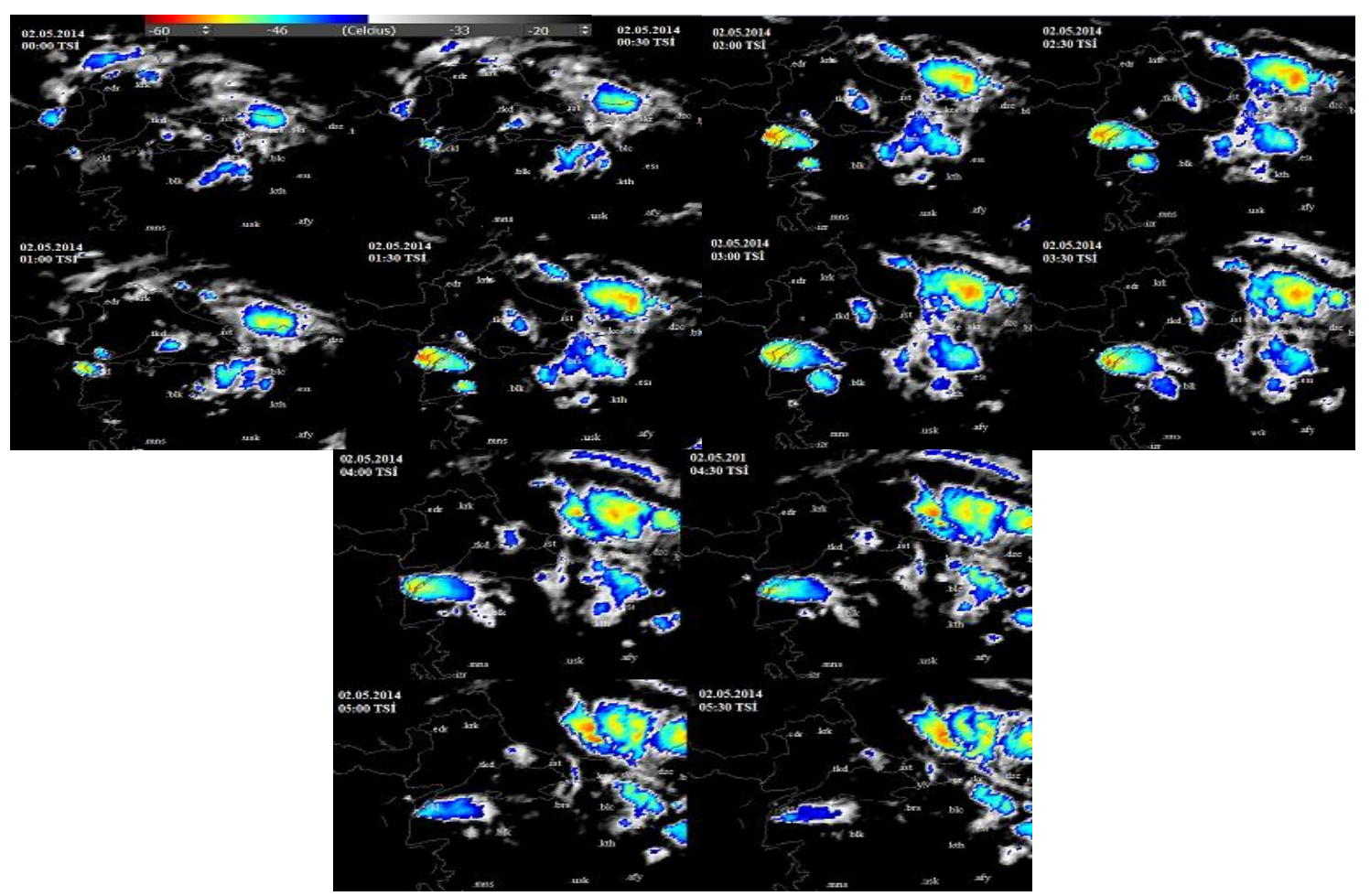

Figure 11. IR Channel 10.8 TMetVis Visualizations

Figure 12 illustrates RGB AirMass application with TMetVis that could be visualizing clearly development of supercell.

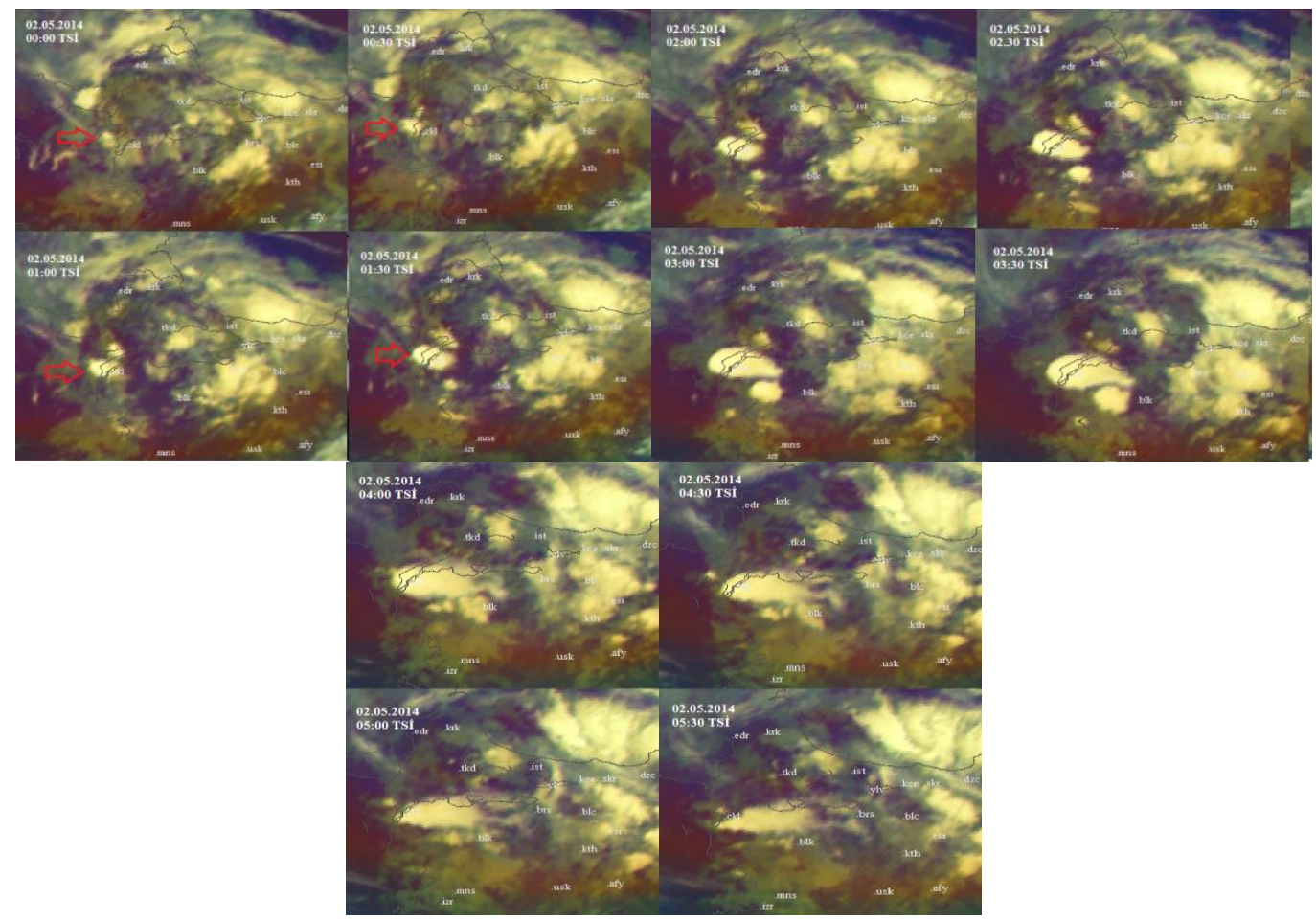

Figure 12. AirMass RGB Applications with TMetVis 


\section{CONCLUSION}

In this study, the flash flood occurred in Gökçeada - Turkey on $2^{\text {nd }}$ of May in 2014 was evaluated by using MSG satellite data and weather charts. According to weather charts, Gökçeada in Agean Sea was affected by a super cell which produces heavy rain, severe winds and lightening. To support weather charts, MSG satellite data, which has 30 minutes timestamp, was showed by using water vapor and infrared 10.8 channels and RGB application named AirMass. Severe weather, which was detected from weather charts, over Gökçeada can be seen from MSG satellite images easily. Satellites as a remote sensing technology are very valuable developments in Science, also in Meteorology.

\section{REFERENCES}

[1] Battan, L.J., Braham, R.R. A study of convective precipitation based on cloud and radar observations. Journal of Meteorology, 13, pp 587-591, 1956.

[2] Dankers R., Feyen L. (2009) Flood hazard in Europe in an ensemble of regional climate scenarios. J. Geophys, Res., 114:D16108.

[3] EM-DAT. The OFDA/CRED international disaster database. Universite Catholique de Louvain Brussels Belgium, 2010.

[4] Intergovernmental Panel on Climate Change (IPCC) Fifth Assessment Report (AR5), 2013.

[5] MetEd. Multispectral Satellite Applications: RGB Products Explained, 2013.

[6] Schmetz, J., Pili, P., Tjemkens, S., Just, D., Kerkmann, J., Rota, S., Ratier, A. An introduction to Meteosat Second Generation (MSG). American Meteo. Soc., pp 972-992, 2002.

[7] Yüksek, Ö., Kankal, M., Üçüncü, O. Assessment of big floods in the Eastern Black Sea Basin of Turkey. Environ. Monit. Assess., 185, pp 979-814, 2013. 
International Scientific Conference GEOBALCANICA 2015 